\title{
Immunogenicity of synthetic peptides representing antigenic determinants on the infectious hematopoietic necrosis virus glycoprotein
}

\author{
E. Emmenegger ${ }^{1,3, *}$, M. Landolt ${ }^{1}$, S. LaPatra ${ }^{2}$, J. Winton ${ }^{3}$ \\ ${ }^{1}$ School of Fisheries, PO Box 357980 University of Washington, Seattle, Washington 98195, USA \\ ${ }^{2}$ Clear Springs Foods, Inc., PO Box 712, Buhl, Idaho 83316, USA \\ ${ }^{3}$ Northwest Biological Science Center, 6505 N.E. 65th St., Seattle, Washington 98115 , USA
}

\begin{abstract}
Three peptides, P76, P226, and P268 representing 3 putative antigenic determinants on the glycoprotein of infectious hematopoietic necrosis virus (IHNV), were synthesized and injected into rainbow trout Oncorhynchus mykiss to assess their immunogenicity. Antisera extracted from the immunized trout were analyzed using an enzyme linked immunosorbent assay (ELISA) for the presence of antibodies that could bind to the peptides or to intact virions of IHNV. The antisera were also tested for neutralizing activity against IHNV by a complement-mediated neutralization assay. In general, recognition of the peptides and IHNV was low and only a few antibody binding patterns were demonstrated. Antisera from fish injected with P76 constructs recognized the homolagous peptide more than the heterologous peptides, whereas antisera from fish inoculated with either P226 or P268 constructs recognized P76 equally, or better, than the homologous peptide; however, there was a high degree of individual variation within each treatment group. Neutralization activity was demonstrated by serum from a single fish injected with one of the peptides (P268) and from 7 of 10 positive control fish infected with an attenuated strain of IHNV. Possible explanations for the dichotomous immune responses are discussed. These results indicate we need to improve our overall understanding of the fish immune system in order to facilitate the development of an efficacious vaccine against IHNV
\end{abstract}

KEY WORDS: IHNV $\cdot$ Immunity Rainbow trout $\cdot$ Synthetic peptides $\cdot$ Vaccine

\section{INTRODUCTION}

Infectious hematopoietic necrosis (IHN) is a viral disease affecting salmonid fishes. Mortalities are especially high among cultured fry, and in some cases losses exceed $90 \%$ (Leong et al. 1988). No effective control measures against the virus currently exist, other than avoidance and destruction of infected stocks (Winton 1991). Survivors of IHN are resistant to re-infection by the causative agent, infectious hematopoietic necrosis virus (IHNV), indicating that immunity against the virus might be induced by an effective vaccine (Amend 1976). However, attempts to control IHN by inducing immunity with vaccines have not been completely successful. An attenuated strain of IHNV

•E-mail: evi_emmenegger@nbs.gov was able to protect vaccinated sockeye Oncorhynchus nerka and chinook $O$. tshawytscha for up to $110 \mathrm{~d}$ (Fryer et al. 1976), but caused unacceptable levels of mortalities in some stocks of vaccinated rainbow trout O. mykiss (Rohovec et al. 1981). Protein sub-unit vaccines against IHNV were reported to provide limited protection (Gilmore et al. 1988, Xu et al. 1991, Noonan et al. 1995), but have not been shown to provide longterm protection, which is a requirement for an IHNV vaccine to be effective (Leong \& Fryer 1993, Winton 1996).

IHNV is a rhabdovirus comprised of 5 structural proteins (Morzunov et al. 1995). The glycoprotein is the primary antigen responsible for eliciting a protective immune response (Engelking \& Leong 1989). Early efforts to map regions on the glycoprotein that are involved with immunity suggested that 3 antigenic 
domains existed at amino acids 270-340, 336-444, and 454-469 (Gilmore et al. 1988, Mourich \& Leong 1991, $\mathrm{Xu}$ et al. 1991). Huang (1993) used a panel of neutralizing monoclonal antibodies (MAb) to isolate a series of neutralization-resistant mutants. Sequencing of the entire glycoprotein (G) gene of 6 of these mutants revealed that they differed from the wild-type by a single amino acid substitution. The substitution sites were located at amino acids (aa) 81, 230-231, and 272-276. The results of the study indicated the presence of 3 possible antigenic domains containing neutralizing epitopes. To investigate the immunogenicity of these antigenic sites identified by Huang (1993), we produced synthetic peptides representing each of the 3 probable antigenic domains and used these to immunize rainbow trout

Synthetic peptides can be used to characterize a suspected antigenic site or to serve as a sub-unit vaccine (Brown et al. 1993). The existence of a B-cell epitope on the envelope protein (gp46) of human T-lymphotrophic virus type 1 (HTLV-1) was confirmed by analyzing sera from rabbits injected with a peptide construct (Env-5) mimicking the epitope (Lairmore et al. 1992). The Env5 anti-sera recognized the Env-5 peptide and the native gp46 protein in an enzyme linked immunosorbent assay (ELISA) and in an immunofluorescence assay. Peptide homologs of a linear epitope (G5) on the rabies virus glycoprotein induced production of virus neutralizing antibodies (Dietzschold et al. 1990) and identified the immunocritical amino acids of the G5 epitope (van der Heijden et al. 1993).

Epitopic peptides have also been used as immunogens to induce protection against the homologous virus. The synthetic peptide (G5-24) that mimics a linear epitope of rabies virus, in combination with a $\mathrm{T}$ helper epitopic peptide, protected immunized mice against a lethal exposure to rabies virus (Dietzschold et al. 1990). Guinea pigs and cattle vaccinated with peptides representing immunogenic regions of the VP1 capsid protein of foot and mouth disease virus (FMDV) were protected from subsequent viral challenge (Bittle et al. 1982, Dimarchi et al. 1986, Steward et al. 1991). Synthetic peptide vaccines are an attractive alternative to the more traditional whole virion vaccines, because they can be strain specific, mass produced inexpensively, have a long shelf-life, and are unable to cause any disease symptoms (Plaue et al. 1990, Arnon \& van Regenmortel 1992).

The 3 synthetic peptides used in this experiment each contained 13 aa residues. Each peptide was presented in 2 different forms to rainbow trout. The forms consisted of the peptide conjugated to either a carrier protein or synthesized directly upon a multiple antigenic peptide (MAP) matrix. The purpose of this study was to determine whether any of the peptide con- structs, when injected into rainbow trout, could stimulate antibody production. The trout sera were analyzed. by ELISA for the presence of antibodies that could bind to the peptides or to intact virions. The sera were also tested by a complement-mediated neutralization assay for the presence of antibodies with the ability to neutralize IHNV. Our results provide information about the humoral immune response of salmonids to synthetic peptides that were designed to mimic the proposed antigenic sites on the glycoprotein of IHNV.

\section{MATERIALS AND METHODS}

Viruses and cells. We used the Western Regional Aquaculture Center (WRAC) strain of IHNV (ATCC VR-1392) isolated in 1982 from rainbow trout in the Hagerman Valley of Idaho, USA. The virus was propagated and assayed using the epithelioma papulosum cyprini (EPC) cell line (Fijan et al. 1983). Cells were grown at $25^{\circ} \mathrm{C}$ in minimum essential media (MEM, Gibco) supplemented with $10 \%$ fetal bovine serum (Gibco), 0.3\% tryptose phosphate broth (Difco), $2 \mathrm{mM}$ L-glutamine (Difco), $2.5 \mu \mathrm{g} \mathrm{m} \mathrm{m}^{-1}$ fungizone (Gibco),

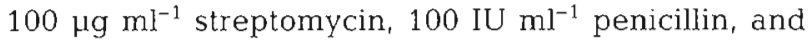
$100 \mu \mathrm{g} \mathrm{ml}^{-1}$ gentamicin sulphate (US Biochem Corp.), and Tris-buffered to $\mathrm{pH} 7.5$

Viral stocks were cultured on EPC monolayers for $7 \mathrm{~d}$ at $15^{\circ} \mathrm{C}$. The culture fluid was harvested and centrifuged at $100000 \times g$ for $20 \mathrm{~min}$ at $4^{\circ} \mathrm{C}$. A subsample of the supernatant was used in a plaque assay (Burke \& Mulcahy 1980) to determine virus concentration. Aliquots of the viral supernatant were stored at $-80^{\circ} \mathrm{C}$ and utilized for positive controls, complement-mediated neutralization assays, and ELISAs. For the ELISA, virus was further purified on discontinuous and continuous sucrose gradients (Hsu et al. 1986) and used as a coating antigen.

Peptide sequence selection. The primary structure of the peptides used in this study was based on amino acid sequences that included the epitopes identified by Huang (1993). The choice of a particular amino acid for initiation of peptide synthesis was determined by the hydropathic values of constituent amino acids (Kyte \& Doolittle 1982) and by the desire to place the immunoreactive site toward the free amino terminus of the peptide construct. Peptide sequences with higher hydrophilicity were selected because they would be more exposed in solution (Grant 1992), increasing their potential to bind to B-cell ligands. The 3 peptide sequences selected for the experiment, designated P76, P226, and P268, are shown in Fig 1

Preparation of peptide inocula. An Applied Biosystems Inc. (ABI) 431A solid phase peptide synthesizer and 9-fluorenylmethoxycarbonyl (Fmoc) protected 


\begin{tabular}{|c|c|}
\hline Peptide $^{a}$ & $\underline{\mathrm{N} \text {-terminus }} \quad \underline{\mathrm{C}}$-terminus $^{\mathrm{b}}$ \\
\hline $\begin{array}{l}\text { P76 } \\
\text { P226 } \\
\text { P268 }\end{array}$ & 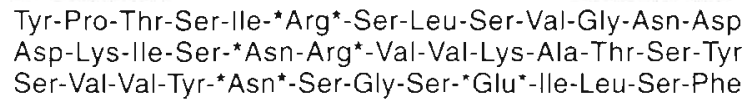 \\
\hline \multirow{2}{*}{\multicolumn{2}{|c|}{$\begin{array}{l}\text { "Delineates immunoreactive sites on the glycoproten as determined by Huang (1993) } \\
\text { "The numbers designate the starting amino acid residue in the peptide (P) based on } \\
\text { the primary structure of the entire IHNV glycoprotein (Koener et al. 1987) }\end{array}$}} \\
\hline & \\
\hline \multicolumn{2}{|c|}{$\begin{array}{l}\text { "Cysteine (Cys) residues were added to the carboxyl terminus of these peptides for } \\
\text { conjugation to a BSA carrier molecule }\end{array}$} \\
\hline
\end{tabular}

Fig. 1. Peptide primary structure
Immunization of rainbow trout. Immunization was conducted in the research laboratories of Clear Springs Foods, Inc., Buhl, Idaho, USA. Ten groups of 2 -yr-old rainbow trout, each weighing approximately $900 \mathrm{~g}$. were anesthetized with tricaine methane sulfonate (MS-222) and received a $500 \mu \mathrm{l}$ intraperitoneal injection of one of the follow ing inocula: P76-Cys-BSA, P226-Cys-BSA, P268-Cys-BSA， P76+MAP8， P226+MAP8, P268+MAP8, a mixture of the 3 MAP8 peptides, BSA (- control), and inactivated IHNV or low virulence IHNV (+ controls). Final peptide concentration administered was approximately $1 \mathrm{mg}$ per trout. Negative controls received $1 \mathrm{mg}$ of BSA. Positive controls received $4.13 \times 10^{7} \mathrm{PFU}$ formalin inactivated IHNV or $3.14 \times 10^{7} \mathrm{PFU}$ of the low virulence IHNV isolate. Prior to injection, a subsample of trout from each tank were anesthetized, bled to obtain a pre-immunization sample $(\sim 1 \mathrm{ml})$, and confirmed negative by the complement-mediated neutralization assay. Each treatment group consisted of 10 Floy-tagged trout randomly distributed among four 1140 l tanks provided with pathogen-free water at $15^{\circ} \mathrm{C}$. Ten non-injected control trout with no known history of IHN were also distributed with the other immunized fish. The 2 groups of positive control fish were isolated in separate tanks.

Collection of sera. Immunized trout were held for a total of $8 \mathrm{wk}$ in pathogen-free water at $15^{\circ} \mathrm{C}$. At $2 \mathrm{wk}$ intervals, the fish were anesthetized and $1 \mathrm{ml}$ volume of blood was removed via caudal puncture. For the final bleeding (Week 8), fish were sacrificed and the maximum amount of blood was extracted. To obtain sera, the blood samples were allowed to clot overnight at $4^{\circ} \mathrm{C}$ and were then centrifuged for $5 \mathrm{~min}$ in a Damon/IEC Hematocrit MB centrifuge. Sera were stored at $-80^{\circ} \mathrm{C}$ until analysis.

Enzyme linked immunosorbent assay (ELISA). Immulon II 96-well microtiter plates (Dynatech Inc.) were coated with $0.1 \mu \mathrm{g}$ of purified IHNV or peptide-MAP8 in a carbonate buffer $(\mathrm{pH} 9.6)$ for $16 \mathrm{~h}$ at $4^{\circ} \mathrm{C}$. Plates were rinsed 3 times with PBS containing $0.05 \%$ Tween 20 detergent (PBST, Sigma) on an automated microplate washer (Bio-tek). Wells were blocked with $3 \%$ $\mathrm{BSA}$ in PBST for $1 \mathrm{~h}$ at $4^{\circ} \mathrm{C}$ and rinsed again. Individual trout serum samples were diluted with $1 \%$ BSA in PBS in a range from $1: 20$ to $1: 2560$ and $100 \mu$ samples of each dilution were added to wells in duplicate and incubated for $16 \mathrm{~h}$ at $17^{\circ} \mathrm{C}$ in a moist chamber. Plates were rinsed with PBST as described previously. One hundred $\mu \mathrm{l}$ of horseradish peroxidase goat anti-trout immunoglobulin (Kirkegaard and Perry) was placed in the sample wells and incubated at room temperature for $1 \mathrm{~h}$. Plates were rinsed 4 times with PBST. One hunlate \#184-90) were the positive controls. 
dred $\mu$ l of the chromagen, a $1: 1$ solution of $0.6 \mathrm{~g} \mathrm{l}^{-1}$ ABTS $[2,2$ ' azino-bis (3-ethylbenzthiazoline 6-sulfonic acid) 1 in a glycine buffer and $0.02 \%$ hydrogen peroxide in a citric acid buffer, was added to the wells and allowed to react for $30 \mathrm{~min}$ at room temperature in a moist chamber. The reaction was stopped by the addition of $100 \mu$ l of $1 \%$ sodium dodecyl sulfate (SDS) to each well. Optical densities (OD) of each sample were measured at $405 \mathrm{~nm}$ using a spectrophotometer plate reader (Bio-tek). A single dilution, either 1:160 or 1:320 for plates coated with IHNV or the peptides, respectively, was selected to maximize the differences between the mean $O D$ of the negative and positive control sera. A sample was designated positive if its average OD value was greater than 2 standard deviations above the mean of the negative control sera. Positive control sera for the assay consisted of a pool of convalescent sera from rainbow trout surviving an IHNV infection. Negative control sera for the assay consisted of a pool of sera from stock rainbow trout with no known previous exposure to IHNV. Specificity of the ELISA was confirmed by pooled convalescent anti-IHNV sera that bound to each of the 3 peptide constructs (P76+MAP8, P226+MAP8, or P268+MAP8) or to purified IHNV, which were used in coating the ELISA plates.

Complement-mediated neutralization assay. This assay was modified from the complement-dependent neutralization test described by LaPatra et al. (1993). All sera were inactivated by incubation for $30 \mathrm{~min}$ at $45^{\circ} \mathrm{C}$. A 2 -fold dilution series of the sera ranging from 1:20 to 1:160 in Hanks' buffered salt solution (HBSS, Sigma) was performed in a 96 -well plate (Costar). Fifty $\mu$ of $10^{4} \mathrm{PFU} \mathrm{ml^{-1 }}$ IHNV was added to all wells and incubated for $30 \mathrm{~min}$ on a rocker platform at $18^{\circ} \mathrm{C}$. The same volume of complement diluted 10 -fold in HBSS was then added to all wells and incubated again under the same conditions.

Twenty-four hour old EPC cell monolayers in 48well plates (Costar \#3548) were pretreated with $10 \mu \mathrm{l}$ per well of $7 \%$ polyethylene glycol (Fisher Chemical) for $10 \mathrm{~min}$. Wells were then inoculated with $50 \mu \mathrm{l}$ of the reaction mixtures in duplicate. Samples were allowed to adsorb to the cells for $1 \mathrm{~h}$ at $18^{\circ} \mathrm{C}$ on a rocker. The inoculum was removed and EPC cells were overlaid with $0.5 \mathrm{ml}$ per well of $0.7 \%$ methylcellulose (Sigma) in MEM with 5\% fetal bovine serum. Cells were incubated for $7 \mathrm{~d}$ at $18^{\circ} \mathrm{C}$, then fixed and stained with a $1 \%$ crystal violet-formalin reagent for $1 \mathrm{~h}$. Neutralization titers were determined by the reciprocal of the highest serum dilution that produced at least a $50 \%$ reduction in the number of plaques relative to negative controls treated with sera pooled from stock rainbow trout with no known exposure to IHNV.

\section{RESULTS}

\section{Mortalities incurred after immunization}

After immunization, fish were monitored daily for mortalities. In general, mortalities were low for all treatment and control groups. Trout immunized with P76-Cys-BSA had the highest cumulative mortality $(30 \%)$. Fish injected with P76+MAP8, P226+MAP8, P226-Cys-BSA, and the low virulence (LV)-IHNV had mortalities of $20 \%$. Fish injected with formalin inactivated (FI)-IHNV experienced $10 \%$ mortality. All other treatment groups had no mortalities. The majority of the mortalities occurred after Week 6 and appeared to be a result of excessive handling during sampling. When compared with controls, fish inoculated with peptide constructs did not have a significant difference in mortality indicating the peptides themselves had no adverse effect on the treated fish.

\section{Recognition of peptides by anti-peptide sera}

When serum samples were collected from each fish at Week 8 and screened by ELISA for the presence of antibodies that bound to homologous and/or heterologous peptides, only a few binding patterns were demonstrated. A significant proportion of the antisera extracted from fish injected with P76+MAP8 or P76Cys-BSA recognized the homologous peptide (P76) more than the heterologous peptides (P226 and P268) (Table 1). In contrast, antisera from fish inoculated with either of the P226 or the P268 constructs recognized P76 equally well or better than the homologous peptide or the other heterologous peptide. Generally, a Iow level of peptide recognition was observed for all antisera tested (Table 1).

The immunogenicity of the peptide inocula could not be determined due to the high degree of individual variation within each treatment group. For example, trout inoculated with P76-Cys-BSA had the highest percentage $(57 \%)$ of positive serum samples that bound to the homologous immunizing peptide (P76) (Table 1). However, this was only slightly greater than the percent $(50 \%)$ of positive samples from the noninjected, negative control sera that bound to the same peptide (P76). Further, 1 sample of P76-Cys-BSA antisera bound only to the heterologous peptide (P226) and 2 antiserum samples bound to none of the peptides. Antibody binding of the antisera from the other treatment groups was similarly variable (Table 1). Sera from positive control fish injected with intact virus (FIIHNV or LV-IHNV) or from negative control (BSA injected and non-injected) fish also recognized the 3 peptides to varying degrees (Table 1). 


\section{Recognition of native virus by anti-peptide sera}

Recognition of native IHNV was low for sera from fish injected with the various peptide constructs. However, positive control sera extracted $6 \mathrm{wk}$ after immunization from fish injected with formalin inactivated (FI-) or low virulence (LV-) IHNV had binding frequencies of 89 and $100 \%$, respectively (Table 2). Among sera from the non-injected (NI) negative control fish, only 1 sample was positive 2 wk post-immunization. All NI serum samples for Weeks 4, 6, and 8 were negative. Binding of negative control sera from BSAinjected fish ranged from $30 \%$ at 2 wk post-immunization to $0 \%$ by Week 8 . Among the test sera, the highest binding rate $(33 \%)$ was noted 6 wk after injection with P76+MAP8. All other test sera demonstrated binding rates less than, or equal to, $30 \%$
Table 1. Recognition of peptides by anti-peptide sera. Serum samples from the 8 -wk bleed were tested by ELISA against 3 peptide coating antigens (P76+MAP8, P226+MAP8, P268+MAP8). A sample was designated positive (i.e binding) if its average $O D$ value was greater than 2 standard deviations above the means of the negative control sera OD at a 1:320 dilution. Mean $O D$ and standard deviation of the negative control sera: P76, $0.285 \pm 0.034$; $P 226,0.808 \pm 0.103 ; \mathrm{P} 268,0.309 \pm 0.046(n=6)$. Number in parentheses represents number of serum samples tested

\begin{tabular}{|lccc|}
\hline Treatment group & \multicolumn{3}{c|}{$\%$ positive samples } \\
& P76 & P226 & P268 \\
\hline P76+MAP8 & $50 \%(8)$ & $12 \%(8)$ & $25 \%(8)$ \\
P226+MAP8 & $57 \%(7)$ & $14 \%(7)$ & $12 \%(8)$ \\
P268+MAP8 & $20 \%(10)$ & $0 \%(10)$ & $20 \%(10)$ \\
Mixed MAP8 & $40 \%(10)$ & $20 \%(10)$ & $30 \%(10)$ \\
P76-Cys-BSA & $57 \%(7)$ & $14 \%(7)$ & $0 \%(7)$ \\
P226-Cys-BSA & $25 \%(8)$ & $25 \%(8)$ & $12 \%(8)$ \\
P268-Cys-BSA & $40 \%(10)$ & $20 \%(10)$ & $0 \%(10)$ \\
Negative control (BSA) & $40 \%(10)$ & $10 \%(10)$ & $0 \%(10)$ \\
Negative control (NI) & $50 \%(8)$ & $12 \%(8)$ & $0 \%(8)$ \\
Positive control (FI-IHNV) & $22 \%(9)$ & $11 \%(9)$ & $11 \%(9)$ \\
Positive control (LV-IHNV) & $12 \%(8)$ & $12 \%(8)$ & $0 \%(8)$ \\
\hline
\end{tabular}

Table 2. Recognition of native virus by anti-peptide sera. Bi-weekly serum samples were tested by ELISA against native IHNV. A sample was designated positive if its average OD value was greater than 2 standard deviations above the means of the negative control sera $O D$ at a 1:160 dilution. Mean $O D$ and standard deviation of the negative control sera: $2 \mathrm{wk}, 0.276 \pm$ $0.041(n=7) ; 4 w k, 0.176 \pm 0.068(n=7) ; 6 w k, 0.182 \pm 0.072(n=6) ; 8 w k$, $0.308 \pm 0.074(n=6)$. Number in parentheses represents number of serum samples tested

\begin{tabular}{|lcccc|}
\hline Treatment group & \multicolumn{4}{c}{$\%$ positive samples } \\
& 2 wk & 4 wk & $6 w k$ & $8 w k$ \\
\hline P76+MAP8 & $0 \%(10)$ & $30 \%(10)$ & $33 \%(9)$ & $25 \%(8)$ \\
P226+MAP8 & $10 \%(10)$ & $10 \%(10)$ & $11 \%(9)$ & $0 \%(7)$ \\
P268+MAP8 & $10 \%(10)$ & $20 \%(10)$ & $10 \%(10)$ & $20 \%(10)$ \\
Mixed MAP8 & $20 \%(10)$ & $20 \%(10)$ & $0 \%(10)$ & $10 \%(10)$ \\
P76-Cys-BSA & $10 \%(10)$ & $10 \%(10)$ & $0 \%(9)$ & $0 \%(7)$ \\
P226-Cys-BSA & $10 \%(10)$ & $10 \%(10)$ & $20 \%(10)$ & $12 \%(8)$ \\
P268-Cys-BSA & $10 \%(10)$ & $10 \%(10)$ & $30 \%(10)$ & $10 \%(10)$ \\
Negative control (BSA) & $30 \%(10)$ & $20 \%(10)$ & $10 \%(10)$ & $0 \%(10)$ \\
Negative control (NI) & $12 \%(8)$ & $0 \%(8)$ & $0 \%(8)$ & $0 \%(8)$ \\
Positive control (FI-IHNV) & $11 \%(9)$ & $22 \%(9)$ & $89 \%(9)$ & $0 \%(9)$ \\
Positive control (LV-IHNV) & $44 \%(9)$ & $11 \%(9)$ & $100 \%(8)$ & $50 \%(8)$ \\
\hline
\end{tabular}

\section{Neutralization activity of the anti- peptide sera}

All of the sera were tested for neutralization of IHNV using a complement-mediated assay. Among all of the sera from the peptide-injected fish ( $\mathrm{n}=70$ ), only one, from a fish injected with P268+MAP8, elicited a strong neutralization titer (Table 3). The sera obtained from this fish at Weeks 4 and 8 had titers greater than 160 , but sera from Weeks 2 and 6 had titers of 0 and 20 , respectively. The serum from this individual also bound to P76, P268 and to native IHNV in the ELISA.

Seventy percent of the LV-IHNV positive control sera had neutralization titers that exceeded 160 at Weeks 4, 6, and 8 (Table 3). Among the 3 fish that did not respond, one (W-8) was lost during the first blood extraction, one (W-13) died immediately after the Week 4 sample was collected, and one ( $\mathrm{W}-11)$ had consistently low titers. Test sera from both negative controls (NI and BSA) and the other positive control (FI IHNV) groups demonstrated no significant neutralization activity (data not shown).

\section{DISCUSSION}

Rainbow trout immunized with various peptide constructs representing putative epitopes on the IHNV glycoprotein produced antisera with little or no ability to recognize either the native virus or the peptides themselves. One explanation for the failure of our peptides to stimulate an immune response could be that the amino acid sequences we chose do not represent epitopes on the glycoprotein of IHNV that are recognized by fish. We selected sequences on the glycoprotein of IHNV based on immunocritical sites identified 
Table 3. Neutralization activity of anti-peptide sera. The P268+MAP8 antisera from fish \#52 represented the only test sera to demonstrate neutralization activity. The titers of all 10 positive control antisera from fish injected with low virulence (LV)-IHNV are also listed. Neutralization titers are expressed as the reciprocal of the highest dilution that corresponded to at least a $50 \%$ reduction in the number of plaques relative to negative control wells. ns: no sample was taken, usually due to mortality

\begin{tabular}{|c|c|c|c|c|c|}
\hline \multirow[t]{2}{*}{ Inoculum treatment } & \multirow[t]{2}{*}{ Tag \# } & \multicolumn{4}{|c|}{ Neutralization titer } \\
\hline & & $2 w k$ & $4 \mathrm{wk}$ & $6 w k$ & $8 w k$ \\
\hline P268+MAP8 & 52 & 0 & $>160$ & 20 & $>160$ \\
\hline Positive control (LV-IHNV) & W3 & 20 & $>160$ & $>160$ & $>160$ \\
\hline Positive control (LV-IHNV) & W4 & 0 & $>160$ & 160 & $>160$ \\
\hline Positive control (LV-IHNV) & W5 & 20 & $>160$ & $>160$ & $>160$ \\
\hline Positive control (LV-IHNV) & W6 & 40 & $>160$ & $>160$ & $>160$ \\
\hline Positive control (LV-IHNV) & W7 & 0 & $>160$ & $>160$ & $>160$ \\
\hline Positive control (LV-IHNV) & W8 & ns & ns & ns & ns \\
\hline Positive control (LV-lHNV) & W9 & 80 & $>160$ & 160 & $>160$ \\
\hline Positive control (LV-IHNV) & W10 & 40 & $>160$ & 160 & $>160$ \\
\hline Positive control (LV-IHNV) & W11 & 0 & 40 & 40 & 0 \\
\hline Positive control (LV-IHNV) & W13 & 0 & 20 & ns & ns \\
\hline
\end{tabular}

aa 274-340 on the IHNV glycoprotein, into mice and rainbow trout. All 5 of the mouse generated antisera bound to the glycoprotein, whereas only 1 peptide laa $321-340$ ) induced the production of trout antisera that reacted with the IHNV glycoprotein. In another report, a cytotoxic T-cell (Tc) epitope on the nucleoprotein of vesicular stomatitis virus (VSV), a mammalian rhabdovirus having a high sequence homology with a region on the nucleoprotein of the fish rhabdovirus, viral hemorrhagic septicemia virus (VHSV), was evaluated for its ability to cross protect (Estepa \& Coll 1993). The immunodominance of this VSV Tc epitope was established in a mouse model. When rainbow trout were immunized with peptides mimicking this Tc epitope and subsequently challenged with VHSV, mortality was significantly greater

by MAbs developed in mice (Huang 1993). Immunogenicity of these mouse-selected epitopes may be low in fish, resulting in little or no antibody production. The proposed epitopes may be immunodominant in mammalian systems, but the more primitive fish immune system may recognize other B-cell epitopes.

Reports in the literature confirm that fish immune cells can recognize different antigenic sites than mammalian lymphocytes. The bacterial fish pathogens Vibrio anguillarum serotype 02 and $V$. ordalii were initially thought to both belong to the same serotype 02 group based on Western immunoblots with rabbit polyclonal antiserum (Chart \& Trust 1984). Based on this assumption, a bivalent vaccine containing killed preparations of $V$. anguillarum serotype 1 and $V$. ordalii was used to vaccinate salmonid smolts (Smith 1988). Subsequent outbreaks of $V$. anguillarum serotype 02 in these fish brought into question the effectiveness of $V$. ordalii in cross-protecting fish against other serotype 02 strains. The antigenic properties of the Vibrio lipopolysaccharide (LPS) were examined by Mutharia et al. (1993) using antisera produced in both rabbits and fish. Rabbits immunized with either of the Vibrio strains produced antibodies that recognized both common and strain-specific epitopes. When these bacteria were injected into fish, common and strainspecific epitopes were also recognized by fish lymphocytes, but these epitopes were different from the antigenic sites recognized by rabbits. Furthermore, protection of fish relied on those strain-specific epitopes uniquely recognized by trout.

Two studies have also tested synthetic peptides as immunogens in a fish host. Mourich \& Leong (1991) injected 5 overlapping synthetic peptides, spanning in immunized fish compared to controls. These examples emphasize the potential problems of studying the antigenicity or immunogenicity of suspected epitopes on fish pathogens using serological data from nonhost species.

If the epitopes on the glycoprotein of IHNV identified by Huang (1993) can be recognized by the trout immune system, an alternative explanation for the low immune response to the peptides is necessary. The lack of immunogenicity for some of the peptides was not entirely unexpected due to their chemical nature. The amino acids in P76 had a net charge of zero and were difficult to dissolve. This was especially crucial when P76 was coupled to the BSA carrier, because successful conjugation was dependent on the peptide remaining in solution. In addition, the hydropathy plot of the IHNV glycoprotein (Koener et al. 1987) revealed that this region was relatively neutral and most epitopes tend to be located in hydrophilic regions (Hopp and Woods 1981). However, the amino acids of $P 76$ had a total hydropathic value of -5.8 , with a greater negative value corresponding to greater hydrophilicity (Kyte \& Doolittle 1982), which should have increased its biological activity

The immunogenicity of peptide-226 (P226) may have been poor because the epitope is conformation dependent. Secondly, the enzymatic stability of this peptide was low (Grant 1992) because the 2 Lys-X and 1 Arg-X amide bonds were susceptible to trypsin-like enzyme degradation and the $\mathrm{N}$-terminal Phe residue linkage can be reduced by chymotrypsin-like enzymes (Fig. 1). This proteolytic activity may have decreased the serum half-life of the peptide, reducing its interaction with the trout immune system. 
One of the immunocritical sites (aa 272) on P268 is believed to be linear (Huang 1993) and is located in a hydrophilic region on the IHNV glycoprotein. For these reasons P268 was expected to be highly immunogenic. This peptide was predicted to be fairly resistant to proteolysis, but the $\mathrm{C}$-terminal Phe-X linkage to the carrier molecule was susceptible to chymotrypsin-like enzyme activity. Smaller peptides are not able to maintain stable secondary structures (Cornette et al. 1989, Wang et al. 1993), but they can bend. The presence of a glycine (Gly) residue in P268 indicates a possible bend and this could have decreased the efficient recognition of the epitopic peptides by $B$ cells (Grant 1992). Another consideration is that the total hydropathic value of P268 was +7.0 , which is slightly hydrophobic and may have lowered the biological activity of the peptide in solution.

A third explanation for the low immunogenicity of the peptides might be the lack of T-cell stimulation. The peptides in this study are most likely B-cell epitopic homologs (Huang 1993); however, both T-helper cell and B-cell epitopic peptides may be required to mount a sufficient immune response in rainbow trout. Classically, large carrier proteins like BSA are used to increase the antigenic mass of an immunogen and provide T-helper cell stimulation; however, MAP8 carrier molecules are considered immunogenically inert (Tam 1988 ) and would provide no T-cell stimulus. Vallejo et al. (1992) stress that determining the $\mathrm{T}$ - and B-cell specificities and effector functions (e.g. proliferative responses, interleukin secretion and cytotoxic activities) of T-cells in fish are essential to vaccine development.

The importance of T-cell activity in the immune response against VHSV has been demonstrated by Estepa et al. (1991). Adherent cells, taken from a mixed culture of kidney cells from immunized trout, were stimulated by both VHSV G and N-proteins, but the adherent cells had a greater response to the $N$-protein than the $G$. The authors felt that the $N$-protein stimulates immunological memory in these immunized cells in vitro as has been previously demonstrated for VSV (Puddington et al. 1986) and rabies viruses (Dietzschold et al. 1987). Further, the $\mathrm{N}$-protein was shown to augment the immune response of fish against IHNV (Oberg et al. 1991, Anderson et al. 1996). It was suggested that the $\mathrm{N}$-protein may stimulate $\mathrm{T}$-helper or $\mathrm{T}$ cytotoxic activity.

Although some trout antisera did exhibit binding activity against the peptides, or native virus, there was a high degree of variation among fish. Most disturbing was the apparent presence of natural antibodies in a few non-injected (NI) negative control fish (Tables 1 \& 2). This variability in antibody binding by fish from the same treatment groups may be a result of distinct char- acteristics present in individual fish that influence their immune response to antigens. These characteristics could include genetic heterogeneity, the presence of natural antibodies, or previous exposure to homologous or cross-reactive heterologous antigens.

Individual variation in immune response due to genetic heterogeneity has been demonstrated in fish (Dorson 1984). Five Renibacterium salmoninarum bacterins were evaluated by Sakai et al. (1993), who found that some rainbow trout within the different treatment groups had high agglutinating antibody titers, whereas other trout receiving the same bacterin had no detectable antibody titer. Van Ginkel et al. (1992) characterized anti-hapten antibodies produced in vitro by channel catfish Ictalurus punctatus peripheral blood lymphocytes (PBL) and compared them to antibodies produced in vivo by the same fish. They observed that the relative quantity of antibodies produced in vitro was equivalent to the number present in that same fish's serum and proposed that genetic predisposition may be responsible for determining the quantity of hapten-specific PBLs in a fish's bloodstream. Individual variation in the proliferation of leucocyctes harvested from rainbow trout that have survived a VHSV infection has been demonstrated. Synthetic peptides representing the G-protein of VHSV were tested in vitro for their ability to stimulate proliferation of rainbow trout kidney leucocytes (Lorenzo et al. 1995). The peptides only stimulated proliferation of leucocytes harvested from survivors of a VHSV infection. Further, the degree of stimulation varied greatly between survivors in both magnitude and type of peptide used.

The use of fish with different major histocompability complex (MHC) haplotypes may explain, in part, the variation seen in antibody binding. Fish $\mathrm{T}$-cell epitopes are presented in conjunction with $\mathrm{MHC}$ molecules in order for immunostimulation to occur (Vallejo et al. 1992). The BSA carrier may have provided T-cell epitopes that were only recognized by certain antigen presenting cells (APC) expressing a specific MHC. In our study, only those fish that possessed the appropriate A.PC could process these T-cell epitopes, link them to the MHC at the cell surface, and then present them to B-lymphocytes. Development of a truly inbred strain of rainbow trout with a defined $\mathrm{MHC}$ would eliminate the ambiguity in evaluating immunogenicity of peptides, due to the genetic homogeneity of the host species. However, this would not facilitate finding the most efficacious vaccine preparations for use in the fisheries industry, where broad genetic diversity is typical and desirable.

Fish to fish variation in immune responsiveness may also be due to natural antibodies, or to previous exposure to homologous or cross-reactive heterologous 
antigens. Fuda et al. (1991) measured serum antibody levels in developing masu salmon Oncorhynchus masou and noted a positive correlation between body weight and immunoglobulin concentrations (with the exception of smolts) for fish up to $489 \mathrm{~d}$ old. The investigators hypothesized that the presence of natural antibodies varies between indjvidual fish and could be due to the normal physiological production of immunoglobulins without antigenic stimulation. Another hypothesis is that a fish immune system is exposed to a variety of external antigens during its lifetime, resulting in 'natural' antibody production (Ingram 1980). These antibodies, which may exhibit cross-reactive binding activity due to low binding specificity, have been detected in rainbow trout (Olesen \& Jørgensen 1986)

Trout used in this experiment were 2 yr old and probably exposed to a variety of antigens prior to immunization. As a result, these older fish may have a greater amount of natural serum antibodies, which could explain the presence of binding antibodies among some trout within certain treatment groups, and from the non-injected and BSA control groups. Only one fish injected with P268+MAP8 produced antisera which neutralized IHNV (Table 3). It seems doubtful that this neutralization activity resulted from an immune response induced by the peptide, since no other antisera from any treatment group exhibited any significant neutralization activity. While unlikely, this fish may have survived an subclinical IHNV infection that was never detected and as a result had a very high neutralization titer (Table 3). The lack of neutralization by the other antisera having some binding activity may be due to a low number of antibodies present. Flamand et al. (1993) determined the number of immunoglobulin (IgG or IgM) molecules required for neutralization of rabies virus at 3 primary antigenic sites. At antibody binding levels up to $130 \mathrm{IgG}$ or $30 \mathrm{IgM}$ molecules per virion, infectivity was still preserved. This may explain why, in our experiment, binding antibodies against IHNV could be present, but neutralization was absent. The peptides may have stimulated the production of antibodies, but at concentrations below the neutralizing dose.

Our results demonstrate the need for a greater fundamental understanding of fish immune mechanisms in order to find an effective means of preventing IHN. Determining the true immunodominant $\mathrm{B}$ - and $\mathrm{T}$-cell epitopes of IHNV that are recognized by fish possessing a range of $\mathrm{MHC}$ haplotypes are critical initial steps. The types of non-specific immunostimuli (i.e. adjuvants and immunostimulants) required for enhancement of the immune response in a particular fish species also need to be assessed. Determining the critical components involved in eliciting an immune response will not only increase our overall understanding of the fish immune system, but will provide us with the information needed to design a successful vaccine for control IHN.

Acknowledgements. This work was supported by a US Fish and Wildlife Service Cooperative Education Agreement. Rainbow trout were graciously provided by Clear Springs Food Inc. (Buhl, Idaho).

\section{LITERATURE CITED}

Amend DF (1976) Prevention and control of viral diseases of salmonids. J Fish Res Bd Can 33:1059-1066

Anderson ED, Mourich DV, Fahrenkrug SC, LaPatra S, Shepherd J, Leong JC (1996) Genetic immunization of rainbow trout (Oncorhynchus mykiss) against infectious hematopoietic necrosis virus. Mol Mar Biol Biotechnol 5:114-122

Arnon R, van Regenmortel MHV (1992) Structural basis of antigenic specificity and design of new vaccines. FASEB $J$ 6:3265-3274

Bittle JL, Houghten RA, Alexander H, Shinnick TM, Sutcliffe JG, Lerner RA, Rowlands DJ, Brown F (1982) Protection against foot-and-mouth disease by immunization with a chemically synthesized peptide predicted from the viral nucleotide sequence. Nature 298:30-33

Brown FJ, Dougan G, Hoey EM, Martin SJ, Rima BK, Trudgett A (1993) Peptides as vaccines. Vaccine design. John Wiley and Sons Ltd, Chichester, p 45-51

Burke JA, Mulcahy D (1980) Plaquing procedure for infectious hematopoietic necrosis virus. J Appl Environ Microbiol 39:872-876

Chart H, Trust TJ (1984) Characterization of the surface antigens of the marine fish pathogens Vibrio anguillarum and Vibrio ordalii. Can J Microbiol 30:703-710

Cornette J L, Margalit H, Delisi C, Berzofsky JA (1989) Identification of t-cell epitopes and use in construction of synthetic vaccines. Methods Enzymol 178:611-634

Dietzschold B, Gore $M$, Marchadier D, Niu H, Bunschoten HM, Otvos L, Wunner WH, Ertl HCJ, Osterhaus ADME, Koprowski H (1990) Structural and immunological characterization of a linear virus-neutralizing epitope of the rabies virus glycoprotein and its possible use in a synthetic vaccine. J Virol 64(8):3804-3809

Dietzchold B, Wang H, Ruppresht CE, Celis E, Tolis M, Ertl H, Katz EH, Koprowski H (1987) Induction of protective immunity against rabies by immunization with rabies virus ribonucleoprotein. Proc Natl. Acad Sci USA 84: 9165-9169

Dimarchi R, Brooki G, Gale C, Cracknell V, Doel T, Mowat N (1986) Protection of cattle against foot-and-mouth disease by a synthetic peptide. Science 232:639-64.1

Dorson M (1984) Applied immunology of fish. In: deKinkelin $P$, Michel $C$ (eds) Symposium on fish vaccination theoretical background and practıcal results on immunization against infectious diseases. Office International des Epizooties, Paris, p 39-74

Engelking HM, Leong JC (1989) The glycoprotein of infectious hematopoietic necrosis virus elicits neutralizing antibody and protective responses. Virus Res 13:213-230

Estepa A, Basurco B. Sanz F, Coll JM (1991) Stimulation of adherent cells by addition of purified proteins of viral hemorrhagic septicemia virus to trout kidney cell cultures. Viral Immunol 4(1):43-52 
Estepa A, Coll JM (1993) Enhancement of fish mortality by rhabdovirus infection after immunization with a viral nucleoprotein peptide. Viral Immunol 6(4):237-243

Fijan N, Sulnmanović D, Bearzotti M, Muzinić D, Zwillenberg LO, Chilmonczyk S, Vautherot JF, dekinkelin P (1983) Some properties of the epithelioma papulosum cyprini (EPC) cell line from carp. Cyprinus carpio. Ann Virol (Paris) 134E:207-220

Flamand A, Raux H, Gaudin Y, Ruigroki RW (1993) Mechanisms of rabies virus neutralization. Virology 194:302-313

Fryer JL, Rohovec JS, Tebbit GL, McMichael JS, Pilcher KS (1976) Vaccination for control of infectious diseases in Pacific salmon. Fish Pathol 10:155-164

Fuda H, Soyano J, Yamazakı F, Hara A (1991) Serum immunoglobulin $M$ (lgMi) during early development of masu salmon (Oncorhynchus masou). Comp Biochem Physiol 99A (4):637-643

Gilmore RD, Engelking HM, Manning DS, Leong JC (1988) Expression in Escherichia coli of an epitope of the glycoprotein of infectious hematopoietic necrosis virus protects against viral challenge. Bio/Technology 6:295-300

Grant GA (1992) Synthetic peptides, a user's guide. WH Freeman and Co, New York

Hopp TP, Woods KR (1981) Prediction of protein antigenic determinants from amino acid sequences. Proc Natl Acad Sci USA 78:3824-3828

Hsu YL, Engelking HM, Leong JC (1986) Occurrence of different types of infectious hematopoietic necrosis virus in fish. Appl Environ Microbiol 52:1353-1361

Huang $C$ (1993) Mapping of antigenic sites of infectious hematopoietic necrosis virus glycoprotein. PhD thesis, University of Washington, Seattle

Ingram GA (1980) Substances involved in the natural resistance of fish to infection. J Fish Biol 16:23-60

Koener JF, Passavant CW, Kurath G, Leong J (1987) Nucleotide sequence of a cDNA clone carrying the glycoprotein gene of infectious hematopoietic necrosis virus, a fish rhabdovirus. J Virol 61(5):1342-1349

Kyte J, Doolittle RF (1982) A simple method for displaying hydropathic character of a protein. J Mol Biol 157:105-132

LaPatra SE, Turner T, Lauda KA, Jones GR, Walker S (1993) Characterization of the humoral response of rainbow trout to infectious hematopoietic necrosis virus. I Aquat Anim Health 5:165-171

Lairmore MD, Rudolph DL, Roberts BD, Dezzutti CS, Lal RB (1992) Characterization of B-cell immunodominant epitope of human t-lymphotropic virus type 1 (HTLV-1) envelope gp46. Cancer Lett 66:11-20

Leong JC, Fryer JL (1993) Viral vaccines for aquaculture Annu Rev Fish Dis 3:225-240

Leong JC, Fryer JL, Winton JR (1988) Vaccination against infectious hematopoietic necrosis virus. In: Ellis AE (ed) Fish vaccination. Academic Press, London p 193-203

Lorenzo GA, Estepa A, Chilmonczyk S, Coll JM (1995) Different peptides from hemorrhagic septicemia rhabdoviral proteins stimulate leucocyte proliferation with individual fish variation. Virology 212:348-355

Moncada C, Torres V, Israel X (1993) Simple method for the preparation of antigen emulsions for immunization. $\mathrm{J}$ Immunol Methods 162:133-140

Morzunov SP, Winton JR, Nichol ST (1995) The complete genome structure and phylogenetic relationship of infectious hematopoietic necrosis virus. Virus Research 38: 175-192

Mourich DV, Leong JC (1991) Mapping of the immunogenic regions of the IHNV glycoprotein in rainbow trout and mice. In: Proceedings of the second international sympo- sium on viruses of lower vertebrates. Oregon State University Press, Corvallis, p 93-100

Mutharia LW, Raymond BT, Dekievit TR, Stevenson RMW (1993) Antibody specificities of polyclonal rabbit and rainbow trout antisera against Vibrio ordalii and serotype $0: 2$ strains of Vibrio anguillarum. Can J Microbiol 39: $492-499$

Noonan B, Enzmann PJ, Trust TJ (1995) Recombinant infectious hematopoietic necrosis virus and viral hemorrhagic septicemia virus glycoprotein epitopes expressed in Aeromonas salmonicida induce protective immunity in rainbow trout (Oncorhynchus mykiss). Appl Environ Microbiol 61(10):3586-3591

Oberg LA, Wirkkula J, Mourich D, Leong JC (1991) Bacterially expressed nucleoprotein of infectious hematopoietic necrosis virus augments protective immunity induced by the glycoprotein vaccine in fish. J Virol 65(8):4486-4489

Olesen NJ, Jorgensen PEV (1986) Quantification of serum immunoglobulin in rainbow trout, Salmo gairdneri under various environmental conditions. Dis Aquat Org 1 183-189

Plaue S, Muller S, Briand JP, Regenmortel MHV (1990) Recent advances in solid-phase peptide synthesis and preparation of antibodies to synthetic peptides. Biologicals 18:147-157

Puddington L, Bevan MJ, Rose JK, Lefrancois L (1986) N protein is the predominant antigen recognized by vesicular stomatitis virus specific cytotoxic $T$ cells. J Virol 60 : $708-717$

Rohovec JS, Fryer JL, Winton JR (1981) Bacterins and vaccines for the control of infectious diseases in fish. In: Kou GH, Fryer JL, Landolt ML (eds) Proceedings of Republic of China-United States cooperative science seminar on fish diseases. NSC Symposium Series 3. National Science Council, Taipei, p 115-121

Sakai M, Atsuta S, Kobayashi M (1993) The immune response of rainbow trout (Oncorhynchus nxykiss) injected with five Renibacterium salmoninarum bacterins. Aquaculture 113: $11-18$

Smith PD (1988) Vaccination against vibriosis. In: Ellıs AE (ed) Fish vaccination. Academic Press, London, p 67-84

Steward MW, Stanely CM, Dimarchi R, Mulcahy G, Doel TR (1991) High-affinity antibody induced by immunization with a synthetic peptide is associated with protection of cattle against foot-and-mouth disease. Immunology 72 : $99-103$

Tam JP (1988) Synthetic peptide vaccine design: synthesis and properties of a high-density multiple antigenic peptide system. Proc Natl Acad Sci USA 85:5409-5413

Vallejo A.N, Miller NW, Clem LW (1992) Antigen processing and presentation in teleost immune responses. Annu Rev Fish Dis 1:73-89

van der Heijden RWJ, Langedijk JPM. Groen J, Uytdehaag FGCM, Meloen RH, Osterhaus ADME (1993) Structural and functional studies on a unique linear neutralizing antigenic site (G5) of the rabies virus glycoprotein. J Gen Virol 74:1539-1545

van Ginkel FW, Miller NW, Lobb CJ, Clem LW (1992) Characterization of anti-hapten antibodies generated in vitro by channel catfish peripheral blood lymphocytes. Dev Comp Immunol 16:139-151

Wang S, Wang X, Deng L, Rassart E, Milne RW, Tail AR (1993) Point mutagenesis of carboxyl-terminal amino acids of cholesteryl ester transfer protein. Opposite faces of an amphipathic helix are important for cholesteryl ester transfer or for binding neutralizing antibody. J Biol Chem 268(3): 1955-1959 
Winton JR (1991) Recent advances in detection and control of infectious hematopoietic necrosis virus in aquaculture. Annu Rev Fish Dis 1:83-93

Winton JR (1996) Vaccination of salmonids against infectious hematopoietic necrosis virus. Dev Biol Stand (in press)

Responsible Subject Editor: J.A. Leong, Corvallis, Oregon, USA
Xu L, Mourich DV, Engelking HM, Ristow S, Arnzen J, Leong JC (1991) Epitope mapping and characterization of infectious hematopoietic necrosis virus glycoprotein, using fusion proteins synthesized in Escherichia coli. J Virol 65(3): $1611-1615$

Manuscript first received: July 11, 1996

Revised version accepted: November 11, 1996 